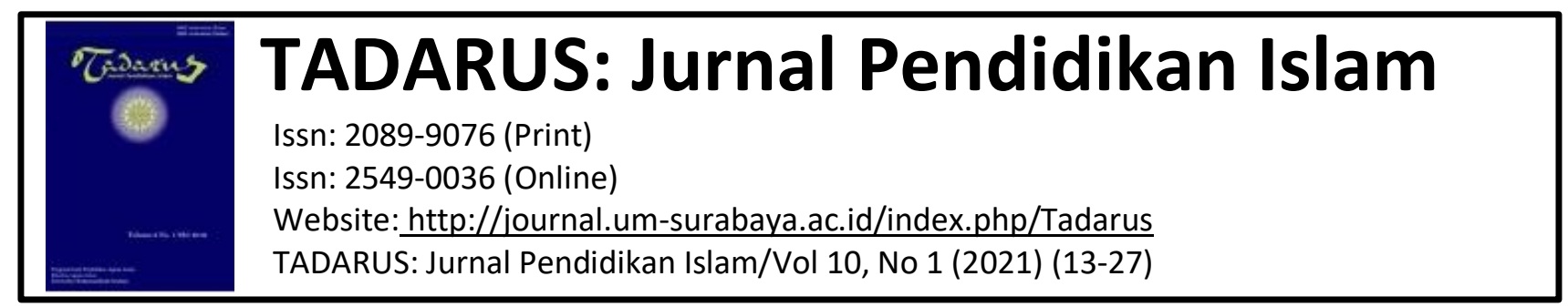

\title{
ANALISIS PERILAKU JAMA'AH MASJID FAQIH OESMAN \\ UNIVERSITAS MUHAMMADIYAH GRESIK DALAM MENGHADAPI \\ PANDEMI COVID-19
}

\author{
Noor Amirudin ${ }^{1}$ \\ ${ }^{1}$ Dosen Program Studi PAI Universitas Muhammadiyah Gresik \\ E-Mail: $\underline{\text { amir@umg.ac.id }}$
}

\begin{abstract}
Abstrak
Awal tahun 2020 ini umat manusia diseluruh dunia tidak pandang bulu digoncang dengan pandemi virus Corona (Covid-19) yang membuat kepanikan dan keresahan dimana-mana. Ratusan ribu manusia terinfeksi dan ribuan lainnya meninggal dunia. Untuk di Indonesia sendiri baik pemerintah dan khususnya Pimpinan Pusat Muhammadiyah telah memberikan himbauanhimbauan kepada masyarakat dan warganya dalam mengatasi wabah ini agar berjalan efektif dan efisien. Tetapi pada kenyataannya masih ada sebagian jama'ah Masjid Faqih Oesman Universitas Muhammadiyah Gresik (UMG) yang belum mengindahkan himbauan tersebut. Oleh karena itu penelitian ini bertujuan untuk menganalisa mengapa sebagian jama'ah Masjid Faqih Oesman UMG memunculkan perilaku yang tidak mematuhi himbauan PP Muhammadiyah maupun pemerintah, dan bagaimana cara mengatasinya. Metode penelitian yang digunakan adalah kualitatif dengan pendekatan deskriptif analisis. Hasil penelitian menunjukan bahwa perilaku yang ditampilkan oleh jama'ah Masjid Faqih Oesman UMG masih kurang mematuhi himbauan Pimpinan Pusat Muhammadiyah maupun pemerintah didasari oleh bias kognitif. Adapun cara mengatasinya dengan pendekatan nilai-nilai dasar ajaran Islam.
\end{abstract}

Kata kunci: perilaku, jama'ah masjid faqih oesman, universitas muhammadiyah gresik 


\section{PENDAHULUAN}

Pada awal tahun 2020 ini dunia dikejutkan dengan wabah virus corona (Covid-19) yang menginfeksi hampir seluruh negara di dunia. WHO Semenjak Januari 2020 telah menyatakan dunia masuk kedalam darurat global terkait virus ini. ${ }^{1}$ Ini merupakan fenomena luar biasa yang terjadi di bumi pada abad ke 21, yang skalanya mungkin dapat disamakan dengan Perang Dunia II, karena eventevent skala besar (pertandingan-pertandingan olahraga internasional contohnya) hampir seluruhnya ditunda bahkan dibatalkan. Kondisi ini pernah terjadi hanya pada saat terjadi perang dunia saja, tidak pernah ada situasi lainnya yang dapat membatalkan acara-acara tersebut. Terhitung mulai tanggal 19 Maret 2020 sebanyak 214.894 orang terinfeksi virus corona, 8.732 orang meninggal dunia dan pasien yang telah sembuh sebanyak 83.313 orang. ${ }^{2}$

Khusus di Indonesia sendiri pemerintah telah mengeluarkan status darurat bencana terhitung mulai tanggal 29 Februari 2020 hingga 29 Mei 2020 terkait pandemi virus ini dengan jumlah waktu 91 hari. $^{3}$ Langkah-langkah telah dilakukan oleh pemerintah dan Pimpinan Pusat Muhammadiyah melalui surat edaran nomor 02/EDR/I.0/E/2020 tentang tuntunan ibadah dalam kondisi darurat covid-19 untuk dapat menyelesaikan kasus luar biasa ini, salah satunya adalah dengan mensosialisasikan gerakan social distancing.

Konsep sosial distancing menjelaskan bahwa untuk dapat mengurangi bahkan memutus mata rantai infeksi covid-19 seseorang harus menjaga jarak aman dengan manusia lainnya minimal 2 meter, dan tidak melakukan kontak langsung dengan orang lain, menghindari pertemuan massal. ${ }^{4}$ Tetapi banyak masyarakat yang tidak menyikapi hal ini dengan baik, seperti contohnya pemerintah sudah meliburkan para siswa dan mahasiswa untuk tidak berkuliah atau bersekolah ataupun memberlakukan bekerja didalam rumah, namun kondisi ini malahan dimanfaatkan oleh banyak masyarakat untuk berlibur6. Selain itu,

${ }^{1}$ R. Sebayang, (2020, Januari 31). Awas! WHO Akhirnya Tetapkan Corona Darurat Global. CNBC Indonesia. Diunduh dari https://www.cnbcindonesia.com/news/20200131060856-4134146/awas-who- akhirnya-tetapkan-corona-darurat-global

${ }^{2}$ Aida, N. R. (2020, Maret 19). Update Virus Corona di Dunia: 214.894 Orang Terinfeksi, 83.313 Sembuh, 8.732 Meninggal Dunia. Kompas.com. Diunduh dari https://www.kompas.com/tren/read/2020/03/19/081633265/update-virus-corona-di- dunia-214894orang-terinfeksi-83313-sembuh-8732

${ }^{3}$ CNN Indonesia. (2020, Maret 14). Mengenal Social Distancing sebagai Cara Mencegah Corona. CNN Indonesia. Diunduh dari https://www.cnnindonesia.com/gaya hidup/20200314102823255-483358/mengenal-social-distancing-sebagai-cara- mencegah-corona

${ }^{4}$ Ibid 
walaupun Indonesia sudah dalam keadaan darurat masih saja akan dilaksanakan tabliqh akbar, dimana akan berkumpul ribuan orang di satu tempat, yang jelas dapat menjadi mediator terbaik bagi penyebaran virus corona dalam skala yang jauh lebih besar. ${ }^{5}$ Serta masih ada sebagian jama'ah masjid faqih oesman UMG yang tidak taat dengan maklumat Pimpinan Pusat Muhammadiyah, diantaranya masih beribadah salat lima watu dan ibadah jum'ah di masjid belum memenuhi protokol kesehatan. ${ }^{6}$ Selain itu masih banyak juga masyarakat umum yang menganggap ringan virus ini, dengan tidak mengindahkan himbauan-himbauan pemerintah.

Perilaku yang tidak normal yang ditunjukan oleh fenomena diatas memicu peneliti untuk menganalisa lebih jauh secara fenomenologi mengapa hal tersebut dapat terjadi di saat kondisi negara sedang dalam keadaan bencana dan bagaimana cara mengatasinya. Selain itu peneliti juga akan memaparkan kiat-kiat dalam menjaga kesejahteraan jiwa dalam menghadapi wabah corona ini melalui pendekatan psikologi positif.

\section{KERANGKA TEORI}

\section{Pandemi Covid-19}

Corona virus adalah keluarga besar virus yang menyebabkan penyakit mulai dari gejala ringan sampai berat. Ada setidaknya dua jenis coronavirus yang diketahui menyebabkan penyakit yang dapat menimbulkan gejala berat seperti Middle East Respiratory Syndrome (MERS) dan Severe Acute Respiratory Syndrome (SARS). Coronavirus Disease 2019 (COVID-19) adalah penyakit jenis baru yang belum pernah diidentifikasi sebelumnya pada manusia. Virus penyebab COVID-19 ini dinamakan Sars-CoV-2. Virus corona adalah zoonosis (ditularkan antara hewan dan manusia). Penelitian menyebutkan bahwa SARS ditransmisikan dari kucing luwak (civet cats) ke manusia dan MERS dari unta ke manusia. Adapun, hewan yang menjadi sumber penularan COVID-19 ini sampai saat ini masih belum diketahui.

\footnotetext{
${ }^{5}$ Hariyadi, D. (2020, Maret 18). Pandemi Corona, Ribuan Orang Ikut Tabligh Akbar se-Asia di Gowa. Tempo.co. Diunduh dari https://nasional.tempo.co/read/1321285/pandem

${ }^{6}$ Hasil Observasi Peneliti pada tanggal 14 Februari 2021 pukul 12.00 WIB di masjid faqih oesman UMG.
} 


\section{Bias Kognitif}

Bias kognitif merupakan sebuah pola penyimpangan dari standar dalam pertimbangan, dimana inferensi bisa terjadi secara tidak wajar. Bias kognitif dapat diartikan juga sebagai opini subjektif atau cenderung yang mungkin berasal dari heuristik spesifik (strategi untuk membuat keputusan) sehingga dapat dinilai sebagai suatu kesalahan dalam berpikir, menilai, mengingat, dan pengambilan keputusan. Bias kognitif dapat menyebabkan seseorang menghasilkan keputusan yang kurang rasional dan kurang komprehensif. ${ }^{7}$

Bias kognitif adalah jenis kesalahan dalam berpikir yang terjadi ketika orang memproses dan menafsirkan informasi di dunia di sekitar mereka. Otak manusia kuat tetapi tunduk pada batasan-batasan tertentu. Bias kognitif seringkali merupakan hasil dari upaya otak manusia untuk menyederhanakan pemprosesan informasi. Itu adalah aturan praktis yang membantu manusia memahami dunia dan mencapai keputusan dengan kecepatan relatif. ${ }^{8}$

Jika bias kognitif dapat memengaruhi orang tersebut dalam pengambilan risiko, maka hal tersebut menjadi penting untuk menentukan bias apa saja yang menyebabkan adanya variasi dalam persepsi risiko. ${ }^{9}$

3. Panduan Pimpinan Pusat Muhammadiyah

Surat Edaran Pimpinan Pusat Muhammadiyah Nomor 02/EDR/I.0/E/2020 tentang tuntunan ibadah dalam kondisi darurat covid-19 pada tanggal 24 Maret 2020, dikeluarkan dengan berpedoman kepada beberapa nilai dasar ajaran Islam dan beberapa prinsip yang diturunkan dari padanya. Nilai-nilai dasar dimaksud adalah Pertama, keimanan kepada Allah Yang Maha Kuasa dan Maha Adil serta Maha Rahman dan Rahim bahwa apa pun yang menimpa manusia tidak lepas dari kehendak Allah Yang Maha Kuasa (QS. Al-Hadid: 22-23). Tetapi semua yang menimpa manusia itu bukanlah karena Allah tidak adil. Sebaliknya Allah itu Maha Adil dan tidak berbuat zalim kepada hamba-Nya (QS. Fushilat: 46). Oleh karena itu segala musibah yang terjadi harus dipandang sebagai suatu ujian bagi manusia (QS. Ali Imran: 142) yang di baliknya banyak hikmah dan pelajaran yang harus dipetik. Antara lain kita harus menjaga kualitas lingkungan hidup kita yang baik dan sehat dan menghindari hal-hal yang merusak termasuk

${ }^{7}$ Y. Barak. The immune system and happiness. Autoimmunity Reviews. 2006, 5(8), pp. 524.

8 D. Kahneman. Thinking, fast and slow. New York: Farrar, Straus and Giroux. Koesmawardhani, N. W. 17 Maret 2011, pp. 99.

${ }^{9}$ T. Sharot. The optimism bias. Current Biology. 2021, 21(23), pp. 945. 
mengundang penyakit dan sekaligus mengingat fungsi kosmik manusia yang bertugas memakmurkan alam (QS. Hud: 61).

Kedua, keimanan bahwa Allah Yang Maha Rahman dan Rahim menuntunkan kepada manusia bahwa dalam menjalani kehidupan agar manusia selalu optimis dan menghindari putus asa. Sikap cepat putus asa itu bukan merupakan sikap orang mukmin, melainkan merupakan tanda ketiadaan iman (QS. Al-Hijr: 56 dan Yusuf: 87). Konsekuensi dari optimisme adalah bahwa kita meyakini bahwa setiap kesulitan selalu ada jalan keluarnya seperti dinyatakan dalam Al-Quran, "Sesungguhnya bersama kesulitan ada kemudahan" (QS. AlInsyirah: 5) dan sabda Nabi saw, “... dan beserta bencana itu ada kelapangan dan bersama kesulitan ada kemudahan" (HR Ahmad, al-Musnad, V: 18, no. 2802, disahihkan oleh al-Arna'ūṭ). Optimisme lebih lanjut bukan suatu sikap menunggu dan berpangku tangan, melainkan melakukan ikhtiar maksimal untuk mencari jalan keluar dari berbagai kesulitan dan menghindari berbagai sumber dari kemudaratan sambil bertawakal kepada Allah. Nasib manusia itu ada di tangan manusia itu sendiri dan apa yang diperolehnya tidak lain adalah hasil usahanya dan Allah tidak akan mengubah nasibnya sebelum ia mengubah keadaan dirinya sendiri (QS. Al-Najm 53: 39 dan Al-Ra'd: 11).

Ketiga, keimanan bahwa ajaran agama itu diturunkan dengan tujuan untuk menjadi rahmat bagi alam semesta (QS. Al-Anbiya': 107) yang oleh para filsuf syariah diterjemahkan sebagai perwujudan maslahat. Kemaslahatan itu adalah perlindungan terhadap manusia baik dalam kehidupan keagamaannya, jiwa raganya, akal pikirannya, institusi keluarganya maupun harta kekayaan yang menjadi sendi kehidupannya. Dalam konteks berkembangnya wabah Covid-10 sekarang perlindungan keberagamaan dan jiwa raga menjadi keprihatinan (concern) kita semua. Dari nilai-nilai dasar ajaran ini diturunkan sejumlah prinsip yang mengutamakan penghindaran kemudaratan dan pemberian kemudahan dalam menjalankan agama yang bertujuan untuk mewujudkan kemaslahatan. ${ }^{10}$

\section{METODE PENELITIAN}

1. Jenis Penelitian

Jenis penelitian ini apabila dilihat dari segi tempat penelitiannya adalah termasuk penelitian lapangan, yaitu penelitian yang bertujuan menggambarkan

10 Edaran Pimpinan Pusat Muhammadiyah Nomor 02/EDR/I.0/E/2020 tentang Tuntunan Ibadah dalam Kondisi Darurat Covid-19 pada tanggal 24 Maret 2020. 
keadaan atau status sebuah fenomena. Oleh karena itu informasi-informasi objek penelitian akan lebih banyak ditemukan di lapangan tempat objek penelitian berada. ${ }^{11}$ Dalam hal ini, peneliti ingin menganalisis sejauhmana pemahaman jama'ah masjid faqih oesman UMG terkait pandemi covid-19 dan bagaimana solusinya.

Adapun pendekatan yang digunakan dalam melaksanakan penelitian ini adalah pendekatan deskriptif kualitatif, metode ini pada hakekatnya adalah mengamati orang dalam kehidupan sehari-hari dalam situasi wajar, berinteraksi bersama mereka, melakukan wawancara serta berusaha memaknai bahasa, kebisaan dan perilaku yang berhubugan dengan fokus penelitian. ${ }^{12}$

Kondisi di atas mengakibatkan peneliti terlibat dalam kehidupan subjek peneliti menjadi suatu tuntutan yang tidak dapat dihindari. Ditegaskan oleh Noeng Muhadjir bahwa dalam melibatkan diri dalam kehidupan subjek penelitian (informan), peneliti akan dapat menjalin hubungan akrab dengan informan, melakukan wawancara mendalam dengan baik serta memahami subjek dengan latar yang alami. ${ }^{13}$

\section{Penentuan Subyek Penelitian}

Metode penentuan subyek yang penulis gunakan adalah Snowball Method yaitu mencari data seperti bola salju yang mengelinding, artinya dalam penentuan subyek dipilih keyinforman (seorang yang dianggap banyak tahu masalah yang diteliti) kemudian baru pada informan-informan yang lain. ${ }^{14}$ Adapun yang menjadi subyek penelitian ini adalah jama'ah masjid faqih oesman UMG.

3. Teknik Pengumpulan Data

Data yang diambil dilapangan tidak terlepas dari teknik pengumpulan data, sehingga dalam penelitian ini akan digunakan teknik sebagai berikut:

a. Observasi. Observasi yaitu cara-cara menghimpun data dengan mengamati dan mencatat gejala-gejala yang sedang diteliti baik secara langsung maupun tidak langsung. ${ }^{15}$ Metode observasi yang peneliti gunakan adalah metode observasi parsitipan yaitu peneliti memposisikan diri dalam lingkungan objek

\footnotetext{
${ }^{11}$ Nazir. M. Metode Penelitian. (Jakarta: Ghalia Indonesia, 1983), hlm. 55.

${ }^{12}$ Lexy J. Moleong. Metodologi Penelitian Kualitatif. (Bandung: Remaja Rosdakarya, 2005), hal. 154.

${ }^{13}$ Noeng Muhadjir. Metode Penelitian Kualitatif. (Yogyakarta: Rake Sarasin, 1996), hlm. 175.

${ }^{14}$ Ibid, hlm. 185-186.

${ }^{15}$ S. Hadi. Metodologi Research Jilid I \& II. (Yogyakarta: Andi Offset, 1989), hlm. 88.
} 
penelitiannya. ${ }^{16}$ Teknik observasi partisipasi yaitu pengumpulan data yang dilakukan dengan cara mengamati dengan terlibat lansung terhadap objek yang diteliti dan mencatat secara sistematis fenomena-fenomena yang akan diselidiki. Oleh karena itu, pada pelaksanaannya peneliti terlibat secara langsung kegiatan solat berjama'ah di masjid.

b. Wawancara. Wawancara adalah percakapan dengan maksud tertentu. Percakapan dilakukan dua pihak, yaitu pewawancara (interviewer) yang mengajukan pertanyaan dan terwawancara (interviewee) yang memberikan jawaban atas pertanyaan itu. ${ }^{17}$ Wawancara dilakukan dengan menggunakan wawancara bebas terpimpin, yaitu menggunakan pedoman yang akan memimpin jalannya tanya jawab sehingga akan diperoleh data-data yang relevan dengan maksud penelitian. ${ }^{18}$ Tujuan dari instrumen teknik ini adalah untuk mengetahui dan memperoleh data yang berkaitan dengan perilaku/pemahaman jama'ah masjid faqih oesman UMG terkait pandemi covid-19.

c. Dokumentasi. Dokumentasi adalah mencari hal-hal atau variabel yang berupa cacatan, transkip, buku, surat kabar, majalah, prasasti, notulen rapat, guru dan agenda dan sebagainya. ${ }^{19}$ Sepadan dengan pendapat lain bahwa teknik dokumentasi adalah cara mengumpulkan data melalui peninggalan tertulis terutama berupa arsip-arsip termasuk juga buku-buku tentang pendapat, teori, dalil atau hukum dan lain-lain yang berhubungan dengan masalah penyelidik. $^{20}$ Dokumentasi ini digunakan untuk pengumpulan data tentang seluruh perilaku jama'ah masjid faqih oesman UMG yang tidak taat terhadap protokol kesehatan.

\section{Analisis Data}

Menurut Patton, metode analisis data adalah proses urutan mengatur data, mengorganisasikannya ke dalam suatu pola, kategori dan satu uraian dasar. Untuk dapat mengatur sambil mengahasilkan uraian dasar dipergunakan metode analisis

${ }^{16}$ W. Surakhmad. Pengantar Penelitian Ilmiah, Dasar Metode dan Teknik. (Bandung: Tarsito, 1992), hlm. 115.

${ }^{17}$ Moleong. L. J. Metodologi Penelitian Kualitatif......., hlm. 178.

${ }^{18}$ A. Sudijono. Pengantar Statistik Pendidikan. (Jakarta: Rajawali Pres, 2011), hlm. 112.

${ }^{19}$ Suharsimi Arikunto. Prosedur Penelitian Suatu Pendekatan Praktek. (Jakarta: PT Rineka Cipta, 1998), hlm. 78.

${ }^{20}$ N. Hadari \& M. Hadawi. Administrasi Personel untuk Produktivitas Kerja. (Jakarta: Haji Masagung, 1990), hlm. 95. 
sesuai dengan ciri pendekatan kualitatif, metode analisa data dilakukan sejak awal, dan dikembangkan selama proses pengumpulan data sampai proses penyusunan laporan. ${ }^{21}$

Proses analisis data, peneliti mengklasifikasikan data menurut temanya, kemudian dipilah-pilah. Data yang diperlukan dikategorikan menjadi beberapa tema utama untuk menjawab pertanyaan-pertanyaan penelitian yang yang telah ditetapkan dan analisis secara deskriptif. Sedangkan data yang kurang relevan dengan pertanyaan-pertanyaan tersebut disimpan. Setelah itu dicoba menginterpretasikan melalui tiga alur kegiatan yang berlangsung secara bersamaan, yaitu reduksi data, penyajian data dan verifikasi. ${ }^{22}$

Pada langkah reduksi, peneliti memilih dan menyederhanakan data dari catatan lapangan. Catatan lapangan yang banyak disederhanakan, disingkat, dirangkum dan dipilih sesuai dengan permasalahan yang telah ditetapkan. Proses reduksi data ini, penulis melakukan pengulangan untuk menghindari terjadinya kekeliruan, hanya data yang berkaitan dengan pokok permasalahan saja yang dipilih, sedangkan yang lain dikeluarkan dari proses analisis. Adapun dalam proses penyajian data, data yang telah penulis pilih melalui reduksi, pemulis sajikan dalam bentuk tulisan atau kata-kata yang sistematis, sehingga mudah untuk disimpulkan. Selanjutnya penarikan kesimpulan yang penulis lakukan selama proses penelitian berlangsung.

\section{HASIL PENELITIAN DAN PEMBAHASAN}

Konsep yang dapat diangkat untuk menjelaskan perilaku jama'ah masjid faqih oesman UMG dalam menghadapi wabah virus Covid-19 ini adalah bias kognitif. Bias kognitif adalah kesalahan sistematis dalam berpikir yang memengaruhi keputusan dan penilaian yang dibuat seseorang. Beberapa bias ini terkait dengan memori. Cara seseorang mengingat suatu peristiwa dapat menjadi bias karena sejumlah alasan tertentu, dan pada gilirannya dapat menyebabkan pemikiran dan pengambilan keputusan yang bias. Bias kognitif lainnya mungkin terkait dengan masalah perhatian. Karena perhatian adalah sumber daya yang terbatas, maka seseorang harus selektif tentang apa yang mereka perhatikan di dunia sekitar mereka. Karena itu, bias-bias halus yang tidak disadari dapat

${ }^{21}$ Moleong. L. J. Metodologi Penelitian Kualitatif......., hlm. 184.

${ }^{22}$ B. Miles \& M. Huberman. Analisis Data Kualitatif Buku Sumber tentang Metode-Metode Baru. (Jakarta: UIP, 1992), hlm. 87. 
merayap masuk dan memengaruhi cara manusia memandang dan berpikir tentang dunia.

Bias kognitif adalah jenis kesalahan dalam berpikir yang terjadi ketika orang memproses dan menafsirkan informasi di dunia di sekitar mereka. Otak manusia kuat tetapi tunduk pada batasan-batasan tertentu. Bias kognitif seringkali merupakan hasil dari upaya otak manusia untuk menyederhanakan pemprosesan informasi. Itu adalah aturan praktis yang membantu manusia memahami dunia dan mencapai keputusan dengan kecepatan relatif. ${ }^{23}$

Bias kognitif ini dibagi menjadi beberapa jenis, dan dalam kasus ini maka peneliti akan mengaitkannya dengan kondisi yang paling tepat dengan fenomena yang diangkat. Bias pertama adalah optimism bias. Bias optimisme adalah bias kognitif yang membuat seseorang percaya bahwa mereka sendiri cenderung tidak mengalami peristiwa negatif. Ini juga dikenal sebagai optimisme tidak realistis atau optimisme komparatif. ${ }^{24}$ Konsep ini dapat menjelaskan mengapa sebagian jama'ah masjid faqih oesman UMG tetap saja tidak takut untuk melakukan aktifitas yang dihadapkan pada orang banyak, solat berjama'ah di masjid contohnya, dikarenakan mereka terlalu percaya diri bahwa corona tidak seberbahaya itu, ini dikarenakan tipikal mereka yang santai menghadapi kondisi apapun, maupun meyakini bahwa Allah akan melindunginya.

Konsep kognitif bias lainnya adalah emotional bias. Bias emosional ini merupakan distorsi dalam kognisi dan pengambilan keputusan karena faktor emosional. Misalnya, seseorang mungkin cenderung untuk menghubungkan penilaian negatif dengan peristiwa atau objek netral; mempercayai sesuatu yang memiliki efek emosional positif, yang memberikan perasaan menyenangkan, bahkan jika ada bukti yang bertentangan; atau enggan menerima fakta nyata yang tidak menyenangkan dan memberikan penderitaan mental. Dari penjelasan ini maka jelas kognisi jama'ah tidak ingin menerima fakta negatif yaitu virus corona jelas membahayakan, tetapi malah mereka mencari sesuatu hal yang memberikan

${ }^{23}$ Haselton, M. G.; Nettle, D. \& Andrews, P. W. (2005). The evolution of cognitive bias. In D. M. Buss (Ed.), The Handbook of Evolutionary Psychology: Hoboken, NJ, US: John Wiley \& Sons Inc. pp. 724-746.

${ }^{24}$ Sharot, T. (2011). The Optimism Bias. Current Biology. 21(23), pp. 941-945. 
perasaan yang menyenangkan misalnya liburan dan jalan-jalan untuk makin menghindari emosi negatif yang berasal dari pandemi ini. ${ }^{25}$

Selanjutnya adalah efek Dunning-Kruger. Bias kognitif ini menjelaskan di mana orang menilai kemampuan kognitif mereka lebih besar daripada kenyataan yang sebenarnya. Hal ini terkait dengan bias kognitif superioritas ilusif dan berasal dari ketidakmampuan orang untuk mengenali kemampuan mereka sesungguhnya. Tanpa kesadaran diri akan metakognisi, orang tidak dapat secara objektif mengevaluasi kompetensi atau ketidakmampuan mereka. Seperti dijelaskan oleh psikolog sosial David Dunning dan Justin Kruger, bias kognitif superioritas ilusi dihasilkan dari ilusi internal pada orang-orang berkemampuan rendah dan dari kesalahan persepsi eksternal pada orang berkemampuan tinggi; yaitu, kesalahan perhitungan orang yang tidak kompeten berasal dari kesalahan tentang diri, sedangkan kesalahan perhitungan orang yang sangat kompeten berasal dari kesalahan tentang orang lain. ${ }^{26}$

Dari konsep yang telah diterangkan di atas maka jama'ah masjid faqih oesman UMG yang tidak mengindahkan himbauan Pimpinan Pusat Muhammadiyah dan pemerintah, memiliki bias kognitif ini, dimana mereka merasa lebih tau atau merasa lebih mengerti kondisi pandemic virus ini, padahal pada kenyataannya itu adalah kesalahan. Contohnya mereka merasa dapat menjaga diri dengan baik walaupun berada di luar rumah atau di keramaian, jadi mereka akan merasa pintar atas dasar persepsi mereka sendiri. Fenomena ini dapat terjadi disebabkan rendahnya kemampuan literasi maupun masih banyak orang yang tidak memiliki akses pada media-media informasi sehingga mereka memiliki minim pengetahuan atas merebaknya wabah Covid-19 ini. Sejalan dengan teori efek Dunning-Kruger maka orang yang memiliki cukup pengetahuan dan referensi literatur akan dapat mematuhi dan melaksanakan anjuran pemerintah dengan baik dan maksimal.

Di dalam pendahuluan juga dijelaskan bahwa masih banyak masyarakat beragama di Indonesia yang masih melakukan kegiatan keagamaan dengan jumlah ribuan orang atau berkumpul bersama-sama untuk melakukan doa

${ }^{25}$ I. Blanchette. 2010. The influence of affect on higher level cognition: A review of research on interpretation, judgement, decision making and reasoning. Cognition and Emotion. 24 (4), pp. 561-595. doi:10.1080/02699930903132496

${ }^{26}$ Justin Kruger \& David Dunning. 1999. Unskilled and Unaware of It: How Difficulties in Recognizing One's Own Incompetence Lead to Inflated Self-Assessments. Journal of Personality and Social Psychology. 77 (6), pp. 1121-1134. CiteSeerX 10.1.1.64.2655. 
bersama. Mereka percaya dengan keyakinan penuh bahwa doa dapat menyelamatkan mereka, dan mereka berpendapat harusnya kita takut kepada Allah bukan kepada virus corona. Situasi ini juga dapat dikatakan kognitif bias dalam beragama sehingga memunculkan dogmatisasi dalam beragama Islam. Model yang dogmatis dapat dikatakan sebagai seseorang yang menerima dengan mentah-mentah begitu saja sesuatu yang ditulis, disampaikan, dan diceritakan dari al-Qur'an dan Hadits tanpa mau menelaah dan berpikir lebih jauh apa makna yang sesungguhnya terkandung dalam al-Qur'an dan Hadits tersebut. Mereka juga terkadang tidak sadar dengan menjadikan agama sebagai sebuah tujuan tetapi bukan sebagai alat untuk menuju tujuan yang sebenarnya yaitu kebenaran sejati dan Allah itu sendiri. Ini dapat ditandai dengan adanya sebagian jama'ah masjid faqih oesman UMG yang menyalahkan individu lainnya dan merasa paling benar. Selain itu ada seseorang yang secara dogmatis akan sulit untuk merubah paradigma yang telah dipercayainya, walaupun hal tersebut belum tentu merupakan kebenaran yang sejati. Ditambah lagi sebagian mereka gampang untuk menghakimi individu yang berbeda dengan pemahamannya dan dengan mudahnya memberikan pernyataan sesat.

Dalam mengatasi bias kognitif tersebut, maka beberapa hal dapat dilakukan melalui rujukan yang disampaikan oleh Kahneman yaitu: Pertama, tidak membuat keputusan dalam waktu yang mendesak. Kemampuan seseorang untuk mendeteksi dan memperbaiki kesalahan dalam suatu penilaian akan secara signifikan memburuk ketika mereka memutuskannya di bawah tekanan dalam jangka waktu yang singkat. Dengan waktu yang sangat cepat biasanya tidak ada kebijaksanaan dalam mengambil keputusan sehingga keputsan yang diambil akan terbukti tidak akurat. Kedua, hindari membuat keputusan ketika seseorang secara kognitif sedang melakukan pekerjaan lebih dari satu. Saat akan mengambil keputusan tetapi seseorang itu juga sedang mengerjakan pekerjaan yang memerlukan fokus, maka akan lebih baik tidak mengambil keputusan, karena otak manusia akan terbagi dalam bekerjanya sehingga keputusan yang diambil tidak akan maksimal. Ketiga, jangan membuat keputusan pada malam hari jika seseorang adalah orang yang beraktivitas atau bekerja yang dimulai pada pagi hari (begitupun sebaliknya). Orang yang beraktifitas pada pagi hari akan berbeda dengan orang yang beraktifitas pada malam hari, sehingga mereka akan merasa segar secara kognitif pada waktu yang berbeda dalam sehari. Dalam hal ini setiap 
orang harus mengetahui kapan waktu yang paling produktif. Dengan mengetahui konsep ini maka seseorang dapat memaksimalkan keputusan yang akan diambil. Keempat, Hati-hati dalam mengambil keputusan saat sedang berbahagia. Penelitian menunjukkan bahwa orang yang sedang berbahagia mengambil keputusan yang lebih buruk. Alasan ini bukan karena orang-orang yang bahagia telah berkurang kapasitas kognitifnya, tetapi karena mereka tidak dapat mendeteksi kesalahan yang bisa terjadi dalam intuisi mereka. Saat seseorang bahagia maka pandangan mereka pada suatu hal akan menjadi sempit pada hal yang positif saja, sehingga mereka menafikan hal negatif yang bisa terjadi. Sebagai contoh saat seseorang sedang jatuh cinta maka hal- hal yang buruk tentang orang yang dicintai akan kabur, dan tidak akan menjadi hal yang signifikan untuk diperhatikan. Kelima, beripikir berdasarkan data dan fakta. Dengan mengerti data-data ataupun fakta yang ada pada kondisi yang sedang dihadapi maka secara kognisi seseorang dapat melihatnya dalam kondisi yang lebih tajam dan luas, sehingga kesalahan dalam mengambil keputusan tidak terjadi. $^{27}$

Selain itu, Keputusan Pimpinan Pusat Muhammadiyah dalam mengatasi permasalahan covid-19 adalah Pertama, keimanan kepada Allah yang Maha Kuasa dan Maha Adil serta Maha Rahman dan Rahim bahwa apa pun yang menimpa manusia tidak lepas dari kehendak Allah Yang Maha Kuasa. Kedua, keimanan bahwa Allah Yang Maha Rahman dan Rahim menuntunkan kepada manusia bahwa dalam menjalani kehidupan agar manusia selalu optimis dan menghindari putus asa. Sikap cepat putus asa itu bukan merupakan sikap orang mukmin, melainkan merupakan tanda ketiadaan iman. Ketiga, keimanan bahwa ajaran agama itu diturunkan dengan tujuan untuk menjadi rahmat bagi alam semesta yang oleh para filsuf syariah diterjemahkan sebagai perwujudan maslahat.

Dengan rincian penjelasan diatas maka diharapkan seluruh masyarakat Indonesia dapat berhati-hati dengan cara berpikir secara matang sebelum melakukan sesuatu pada kondisi pandemi virus corona yang menyerang Indonesia. Semakin hati-hatinya semua masyarakat dalam bertindak maka virus

${ }^{27}$ D. Kahneman. (2011). Thinking, fast and slow. New York: Farrar, Straus and Giroux. 
Covid-19 dapat dengan cepat diatasi dan ditanggulangi sehingga juga dapat mempermudah kerja dari pemerintah.

\section{KESIMPULAN}

Beberapa jama'ah masjid faqih oesman Universitas Muhammadiyah Gresik yang tidak mematuhi himbauan dari Pimpinan Pusat Muhammadiyah dan pemerintah untuk menanggulangi pandemi virus corona ini, diakibatkan oleh salah satu konsep di dalam psikologi yang dinamakan bias kognitif. Bias kognitif adalah kesalahan sistematis dalam berpikir yang memengaruhi keputusan dan penilaian yang dibuat seseorang. Jenis bias kognitif yang tepat untuk menjelaskan fenomena ini adalah bias optimism, bias emosional, dan efek Dunning-Kruger.

Mengatasi bias kognitif ini langkah-langkah yang dapat dilakukan oleh jama'ah masjid faqih oesman Universitas Muhammadiyah Gresik dan masyarakat pada umumnya adalah: 1) tidak membuat keputusan dalam waktu yang mendesak; 2) hindari membuat keputusan ketika seseorang secara kognitif sedang melakukan pekerjaan lebih dari satu; 3) jangan membuat keputusan pada malam hari jika seseorang adalah orang yang beraktivitas atau bekerja yang dimulai pada pagi hari (begitupun sebaliknya); 4) hati-hati dalam mengambil keputusan saat sedang berbahagia; 5) berpikir berdasarkan data dan fakta; 6) beriman kepada Allah Yang Maha Kuasa dan Maha Adil serta Maha Rahman dan Rahim bahwa apa pun yang menimpa manusia tidak lepas dari kehendak-Nya. 


\section{REFERENSI}

Aida, N. R. (2020, Maret 19). Update Virus Corona di Dunia: 214.894 Orang Terinfeksi, 83.313 Sembuh, 8.732 Meninggal Dunia. Kompas.com. Diunduh dari https://www.kompas.com/tren/read/2020/03/19/081633265/update-virus-corona-didunia-214894-orang-terinfeksi-83313-sembuh-8732

Arikunto, Suharsimi. 1998. Prosedur Penelitian Suatu Pendekatan Praktek. Jakarta: PT Rineka Cipta.

Barak, Y. 2006. The immune system and happiness. Autoimmunity Reviews, $5(8)$.

Blanchette, I. 2010. The influence of affect on higher level cognition: A review of research on interpretation, judgement, decision making and reasoning. Cognition and Emotion. 24 (4), pp. 561-595. doi:10.1080/02699930903132496

CNN Indonesia. (2020, Maret 14). Mengenal Social Distancing sebagai Cara Mencegah Corona. CNN Indonesia. Diunduh dari https://www.cnnindonesia.com/gaya hidup/20200314102823-255-483358/mengenalsocial-distancing-sebagai-cara- mencegah-corona

Edaran Pimpinan Pusat Muhammadiyah Nomor 02/EDR/I.0/E/2020 tentang Tuntunan Ibadah dalam Kondisi Darurat Covid-19 pada tanggal 24 Maret 2020.

Hadari, N. \& Hadawi, M. 1990. Administrasi Personel untuk Produktivitas Kerja. Jakarta: Haji Masagung.

Hadi, S. 1989. Metodologi Research Jilid I \& II. Yogyakarta: Andi Offset.

Hariyadi, D. (2020, Maret 18). Pandemi Corona, Ribuan Orang Ikut Tabligh Akbar se-Asia di Gowa. Tempo.co. Diunduh dari https://nasional.tempo.co/read/1321285/pandem

Haselton, M. G.; Nettle, D. \& Andrews, P. W. 2005. The evolution of cognitive bias. In D. M. Buss (Ed.), The Handbook of Evolutionary Psychology: Hoboken, NJ, US: John Wiley \& Sons Inc.

Kahneman, D. 17 Maret 20011. Thinking, fast and slow. New York: Farrar, Straus and Giroux.

Kruger, J. \& Dunning, D. 1999. Unskilled and Unaware of It: How Difficulties in Recognizing One's Own Incompetence Lead to Inflated Self-Assessments. Journal of Personality and Social Psychology. 77 (6). CiteSeerX 10.1.1.64.2655

Miles, B \& Huberman, M. 1992. Analisis Data Kualitatif Buku Sumber tentang Metode-Metode Baru. Jakarta: UIP. 

Sarasin.

Muhadjir. Noeng. 1996. Metode Penelitian Kualitatif. Yogyakarta: Rake

Moleong, Lexy J. 2005. Metodologi Penelitian Kualitatif. Bandung: Remaja Rosdakarya.

Nazir, M. 1983. Metode Penelitian. Jakarta: Ghalia Indonesia.

Sebayang, R. (2020, Januari 31). Awas! WHO Akhirnya Tetapkan Corona Darurat Global. CNBC Indonesia. Diunduh dari https://www.cnbcindonesia.com/news/20200131060856-4-134146/awas-whoakhirnya-tetapkan-corona-darurat-global

Sharot. T. 2021. The optimism bias. Current Biology, 21(23).

Sudijono, A. 2011. Pengantar Statistik Pendidikan. Jakarta: Rajawali Pres.

Surakhmad, W. 1992. Pengantar Penelitian Ilmiah, Dasar Metode dan Teknik. Bandung: Tarsito. 